\title{
複数本の溶接鉄筋を用いた $\mathrm{RC}$ はりの 疲労強度の推定方法
}

\author{
二 羽 淳一郎 $*^{1} \cdot$ 榎 本 松 司 $*^{2}$. 岡 村 甫*3
}

\section{1. 序論}

土木学会では現在, 昭和 61 年度のコンクリート標準 示方書の限界状態設計法への移行を控えて, 各限界状態 に対する設計方法の改定作業が進められている。このな かで, 疲労限界状態は検討すべき限界状態の一つとして 取り上げられているが，これを検討するためには，繰返 し外力を受ける鉄筋コンクリート $(\mathrm{R} \mathrm{C})$ 部材の疲労特性 を明らかにしておく必要がある。本論はこのような条件 を念頭におき，曲げを受ける R C 構造部材の疲労強度の うち, 特に複数本の溶接鉄筋を使用した場合の部材全体 の疲労強度の推定方法について一つの考え方を提示する ものである。

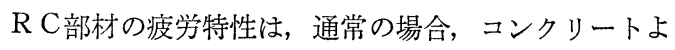
りは，むしろ鉄筋の疲労特性に支配されることが多い。 したがって, 部材の疲労特性を検討するに際しては鉄筋 の疲労特性を明らかにすることが事実上重要であり, こ

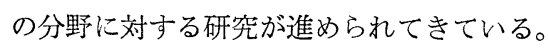

ただし, 従来までの研究は構造材料としての鉄筋単体 の疲労強度に着目したものが多く, 例えげ曲げを受ける 場合でも, 主鉄筋として複数本使用された場合の部材全 体としての疲労強度と, 鉄筋単体としての疲労強度とを 明確に区別して検討されることはほとんどなかったもの と思われる。

これは, 異形鉄筋の疲労破断が鉄筋のフシ端部から発 生することが一般的であり, かつフシが 1 本の鉄筋中に 多数含まれていることによるものと考えられる。すなわ ち, 鉄笳の疲労破断が鉄筋中の最弱のフシの疲労強度に 支配されるものと考えれば，1本の鉄筋中には既に多数 のフシが存在しているので, その疲労強度はほとんど絶 対的な最弱フシの疲労強度に近く, それ以上多少鉄筋本 数が増加したとしても, 本数全体としての最弱フシの疲

\footnotetext{
*1 正会員 東京大学講師 工学部土木工学科

$* 2$ 東京大学技官 工学部土木工学科

*3 正会員 東京大学教授 工学部土木工学科
}

Vol. 23, No. 5, May 1985
労強度が著しく低下していくことはないと考えられるか らである。

異形鉄筋の疲労に対する弱点がフシであるのに対し て, 溶接鉄筋の疲労に対する弱点箇所が溶接部であるこ とは残念ながら避けることができないと考えられる。異 形鉄筋の場合は 1 本の鉄筋中のフシの数が多数であるた めに，上述のように使用本数の増加による疲労強度の低 減をほとんど考慮しなくともよいと考えられるが，溶接 鉄筋の場合核点となる箇所がわずかであるが故に，か えってその増加による影響が相対的に大きく，溶接鉄筋 本数の増加に伴う部材全体としての疲労強度の低下を考 慮していく必要があると考えられるのである。

溶接鉄筋の疲労破断が溶接部の疲労強度に支配され, その疲労強度がある程度変動することを考慮すれば, 溶 接鉄筋を複数本使用した場合には, 溶接鉄筋を 1 本使用 した場合に比較して, 部材としての疲労強度が使用本数 に比例して増加していくとは考えられず，むしろそれよ りは幾分低下していくことが予測される。

したがって, 溶接鉄筋単体としての疲労強度から, 部 材全体としての疲労強度を推定することが, 設計上必要 となってくる。

本論は, 溶接鉄筋を主鉄筋とするはりの疲労試験を行 い, 溶接鉄筋を単体として使用した場合と, 使用した溶 接鉄筋の本数を変化させた場合とで, 疲労特性がどのよ うに変化していくかに着目して実験データを蓄積し, 溶 接鉄筋 1 本の疲労強度の特性を明らかにすることによ り，溶接鉄筋を主鉄筋として複数本配置した場合の部材 全体としての疲労強度を推定することを試みたものであ る。

\section{2. 実験方法}

実験を行ったはりは 3 種類で，このうち溶接鉄筋を含 むものは, 主鉄筋として溶接鉄筇と溶接されていない鉄 筋母材を各 1 本, 計 2 本用いたII タイプと, 3 本の溶接 鉄筋のみを使用したIIIタイプである。なお，鉄筋母材の 
疲労強度を知るために，溶接されていない鉄筋母材のみ を2本用いたIタイプの疲労試験もあわせて行った。

はりの形状は, 桁高 $30 \mathrm{~cm}$, 幅 $20 \mathrm{~cm}$ (I タイプおよ びII タイプ) または幅 $30 \mathrm{~cm}$ (III タイプ) の矩形断面で あり，有効高さはいずれも $25 \mathrm{~cm}$ である。供試体の長さ はすべて $180 \mathrm{~cm}$ である(図一1)。

主鉄筋は D 19 (SD 35) であり, 降伏強度 $41.3 \mathrm{~kg} /$ $\mathrm{mm}^{2}$, 引張強度 $58.7 \mathrm{~kg} / \mathrm{mm}^{2}$ である(表一1)。フシは 斜めフシであり, フシと鉄筋軸とのなす角度は 60 度で ある。また，フシの根元には円弧が設けられていない。 溶接鉄筋は鉄筋相互間の端部を突き合せ，自動アーク溶 接によって接合したものである（写真一1）。

溶接鉄筋の溶接部はすべてスパンの中央に配置した。 今回の実験では, 主鉄筋の破断によるはりの破壊を目的 としており，試験時にはりがせん断破壊するのを防止す るために，せん断スパン内には D 10 を加工した鉛直ス ターラップを $12 \mathrm{~cm}$ ピッチ (I タイプおよびII タイプ) または $9 \mathrm{~cm}$ ピッチ (IIIタイプ) で配置してある。これ らの溶接鉄筋抢よび腹鉄筋はすべて三井造船（株）より 提供を受けた。
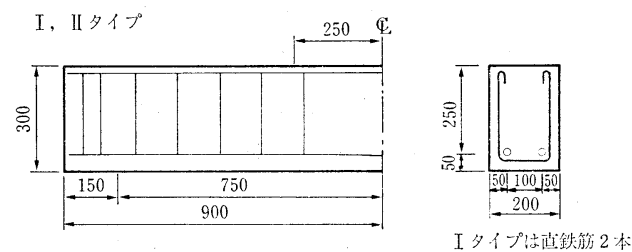

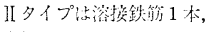

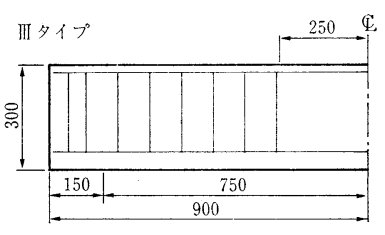
计鉄筋 1 本

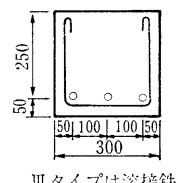

III タイプは溶接鉄筋 3 本 临估 $(\mathrm{mm})$

図一1供試体および鉄筋配置

表一1 使用した鉄筋の性質

\begin{tabular}{c|c|c|c|c|c}
\hline 呼び径 & 規 格 & $\begin{array}{c}\text { 公称断面積 } \\
\left(\mathrm{cm}^{2}\right)\end{array}$ & $\begin{array}{c}\text { 降 伏 強 度 } \\
\left(\mathrm{kg} / \mathrm{mm}^{2}\right)\end{array}$ & $\begin{array}{c}\text { 引 張 強 度 } \\
\left(\mathrm{kg} / \mathrm{mm}^{2}\right)\end{array}$ & $\begin{array}{c}\text { †ング係数 } \\
\left(\mathrm{kg} / \mathrm{cm}^{2}\right)\end{array}$ \\
\hline $\mathrm{D} 19$ & $\mathrm{SD} 35$ & 2.865 & 41.3 & 58.7 & $1.82 \times 10^{6}$ \\
\hline
\end{tabular}

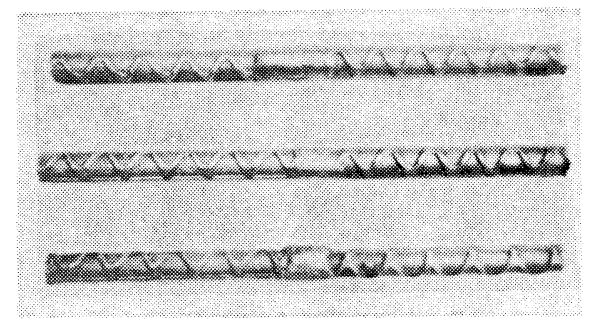

写真ー1 使用した自動アーク溶接鉄筋
使用したコンクリートは, 粗骨材最大寸法 $20 \mathrm{~mm}$, ス ランプ $8 \mathrm{~cm}$ のレデーミクストコンクリートである。疲 労試験中のコンクリート強度の変化の影響を取り除くた

表一2 疲労試 験 結 果

\begin{tabular}{|c|c|c|c|c|c|c|c|}
\hline No. & 供試体名 & $\begin{array}{c}f_{c^{\prime}}^{\prime} \\
\left(\mathrm{kg} / \mathrm{cm}^{2}\right)\end{array}$ & $\left(\begin{array}{c}\sigma_{s} \cdot \min \\
\left(\mathrm{kg} / \mathrm{mm}^{2}\right)\end{array}\right.$ & $\begin{array}{c}\sigma_{s \cdot \max } \\
\left(\mathrm{kg} / \mathrm{mm}^{2}\right)\end{array}$ & $\begin{array}{c}N \\
(\times 1000)\end{array}$ & $\mid \begin{array}{l}\text { 破壞モ } \\
\text { ード* }\end{array}$ & $\begin{array}{l}\text { 溶接 } \\
\text { 本数 }\end{array}$ \\
\hline \multirow[t]{3}{*}{1} & \multirow[t]{3}{*}{$I-1$} & \multirow[t]{3}{*}{347} & 5.0 & 20.1 & 2080 & $\mathrm{~N}$ & 0 \\
\hline & & & 5.0 & 25.1 & 1860 & $\mathrm{~N}$ & 0 \\
\hline & & & 5.0 & 30.1 & 556 & $\mathrm{~S}$ & 0 \\
\hline 2 & $\mathrm{I}-2$ & 343 & 5.0 & 30.1 & 953 & B & 0 \\
\hline \multirow[t]{2}{*}{3} & \multirow[t]{2}{*}{$I-3$} & \multirow[t]{2}{*}{360} & 5.0 & 25.1 & 2120 & $\mathrm{~N}$ & 0 \\
\hline & & & 5.8 & 28.9 & 364 & $\mathrm{~S}$ & 0 \\
\hline 4 & $I-4$ & 356 & 5.8 & 28.9 & 810 & B & 0 \\
\hline 5 & $I-5$ & 351 & 5.5 & 27.6 & 940 & B & 0 \\
\hline 6 & $I-6$ & 352 & 5.3 & 26.3 & 2210 & B & 0 \\
\hline 7 & $I-7$ & 327 & 14.7 & 36.8 & 232 & B & 0 \\
\hline 8 & $I-8$ & 332 & 14.7 & 36.8 & 646 & B & 0 \\
\hline 9 & $I-9$ & 360 & 9.4 & 31.5 & 3550 & $B$ & 0 \\
\hline 10 & $I-10$ & 360 & 9.9 & 33.0 & 1323 & $\mathrm{~S}$ & 0 \\
\hline 11 & II -1 & 347 & 5.0 & 20.1 & 2104 & B & 1 \\
\hline 12 & III-2 & 347 & 5.0 & 25.1 & 264 & B & 1 \\
\hline 13 & II -3 & 343 & 4.4 & 22.1 & 1081 & B & 1 \\
\hline 14 & II -4 & 342 & 5.0 & 25.1 & 591 & $B$ & 1 \\
\hline 15 & $I I-5$ & 360 & 4.4 & 22.1 & 611 & B & 1 \\
\hline 16 & II -6 & 356 & 5.0 & 20.1 & 1806 & B & 1 \\
\hline 17 & II -7 & 356 & 5.0 & 25.1 & 268 & $B$ & 1 \\
\hline 18 & II -8 & 346 & 10.0 & 25.1 & 897 & $B$ & 1 \\
\hline 19 & II -9 & 351 & 10.0 & 25.1 & 790 & B & 1 \\
\hline 20 & II -10 & 352 & 8.7 & 21.7 & 762 & B & 1 \\
\hline 21 & II -11 & 352 & 8.7 & 21.7 & 1372 & B & 1 \\
\hline 22 & II -12 & 348 & 11.8 & 29.4 & 565 & $\mathrm{~B}$ & 1 \\
\hline \multirow[t]{2}{*}{23} & \multirow[t]{2}{*}{ II -13} & \multirow[t]{2}{*}{327} & 7.4 & 18.4 & 2200 & $\mathrm{~N}$ & 1 \\
\hline & & & 8.0 & 20.1 & 1160 & $B$ & 1 \\
\hline \multirow[t]{2}{*}{24} & \multirow[t]{2}{*}{ II -14} & \multirow[t]{2}{*}{327} & 7.4 & 18.4 & 2160 & $\mathrm{~N}$ & 1 \\
\hline & & & 8.0 & 20.1 & 1520 & B & 1 \\
\hline 25 & II -15 & 332 & 7.3 & 24.4 & 555 & B & 1 \\
\hline \multirow[t]{2}{*}{26} & \multirow[t]{2}{*}{ II -16} & \multirow[t]{2}{*}{332} & 5.6 & 18.6 & 2190 & $\mathrm{~N}$ & 1 \\
\hline & & & 6.4 & 21.5 & 1763 & B & 1 \\
\hline 27 & II -17 & 357 & 7.4 & 29.7 & 163 & B & 1 \\
\hline 28 & II -18 & 357 & 6.7 & 26.8 & 163 & B & 1 \\
\hline 29 & II -19 & 360 & 6.0 & 20.1 & 1595 & B & 1 \\
\hline 30 & II -20 & 360 & 8.7 & 21.7 & 1520 & B & 1 \\
\hline 31 & III- 1 & 347 & 5.0 & 20.0 & 594 & B & 3 \\
\hline 32 & III -2 & 347 & 5.0 & 22.1 & 267 & B & 3 \\
\hline 33 & III -3 & 343 & 4.4 & 22.1 & 349 & $B$ & 3 \\
\hline 34 & III -4 & 343 & 3.3 & 16.3 & 1144 & B & 3 \\
\hline 35 & III - 5 & 360 & 3.1 & 15.3 & 965 & B & 3 \\
\hline 36 & III -6 & 356 & 3.3 & 16.3 & 1087 & B & 3 \\
\hline 37 & III -7 & 356 & 5.0 & 20.0 & 306 & $B$ & 3 \\
\hline 38 & III -8 & 346 & 3.1 & 15.3 & 1924 & B & 3 \\
\hline 39 & III - 9 & 351 & 8.7 & 21.8 & 805 & $B$ & 3 \\
\hline 40 & III -10 & 351 & 8.7 & 21.8 & 658 & $B$ & 3 \\
\hline 41 & III -11 & 352 & 7.4 & 18.4 & 896 & B & 3 \\
\hline 42 & III -12 & 348 & 7.4 & 18.4 & 1254 & B & 3 \\
\hline \multirow[t]{2}{*}{43} & III -13 & 327 & 6.7 & 16.7 & 2130 & $\mathrm{~N}$ & 3 \\
\hline & & & 7.0 & 17.5 & 2130 & B & 3 \\
\hline 44 & III -14 & 332 & 6.0 & 18.4 & 1503 & B & 3 \\
\hline 45 & III -15 & 332 & 5.2 & 17.2 & 1850 & $\mathrm{~B}$ & 3 \\
\hline 46 & III -16 & 332 & 10.8 & 27.1 & 119 & $B$ & 3 \\
\hline 47 & III -17 & 357 & 4.7 & 15.7 & 2230 & $\mathrm{~N}$ & 3 \\
\hline & & & 8.2 & 22.3 & 249 & B & 3 \\
\hline 48 & III -18 & 357 & 5.6 & 18.6 & 1533 & B & 3 \\
\hline 49 & III -19 & 360 & 8.2 & 22.3 & 658 & B & 3 \\
\hline 50 & III -20 & 360 & 8.0 & 20.0 & 1290 & $\mathrm{~B}$ & 3 \\
\hline
\end{tabular}

$* \mathrm{~B}$ : 破壊, $\mathrm{N}$ : 非破壤, $\mathrm{S}:$ : ん断破懐 
め, コンクリート打設後, 2 ケ月以上経過させてから疲 労試験を開始した。試験時のコンクリートの圧縮強度 $f_{c}^{\prime}$ は $327 \sim 360 \mathrm{~kg} / \mathrm{cm}^{2}$ の範囲内であった（表一2）。

載荷方法はスパン $150 \mathrm{~cm}$, せん断スパン $50 \mathrm{~cm}$ の対 称 2 点載荷である (図一1)。鉄筋に作用させる最小応力 $\sigma_{s . \min }, お よ ひ ゙$ 最大応力 $\sigma_{s . \max }$ を設定したのち, コン クリートの引張力を無視し, ヤング係数比 $n$ を 7 とした 計算を行って作用させる疲労荷重を求めた。

鉄筋に所定のひずみが生じることを確認するために, IIタイプおよび亚タイプではスパン中央の溶接位置より 支点側に $20 \mathrm{~cm}$ 離れたはり下面にあらかじめ切欠きを設 けて，曲げひびわれが入るようにしておき，その位置の 鉄筋の下面にストレインゲージを貼付して鉄筋ひずみを 測定した。

測定された鉄筋ひずみから, 応力振幅 $\sigma_{r}\left(=\sigma_{s}\right.$.max $\left.\sigma_{s . \mathrm{min}}\right)$ の実測值を求め, 設定した応力振幅と比較した 結果, IIタイプではこれらの比のタイプ全体の平均值が 1.00 , 変動係数 $4.9 \%$, またIII タイプでは同じく平均值 0.94 , 変動係数 $6.2 \%$ となった。いずれの場合も, 変動 係数が十分に小さいことを考慮し, 以後の検討に用いる 鉄筋の応力度には設定值をそのまま用いることとした。

\section{3. 実験結果の概要}

\subsection{I タイプの実験結果}

溶接鉄筋 1 本当りに加える応力振幅の目安とするため に, 鉄筋母材自体の疲労強度を実験的に求めることとし た。このため, Iタイプとして鉄筋母材のみを 2 本用い た 10 体のはりを製作し, 疲労試験を行った。

作用応力振幅 $\sigma_{r}$ は $15.1 \sim 25.1 \mathrm{~kg} / \mathrm{mm}^{2}$, 最小応力 と最大応力の比 $r\left(=\sigma_{s . \min } / \sigma_{s . \max }\right)$ は $0.17 \sim 0.40$ であ り,これらをランダムに設定した。実験結果は表一2 に 示したが，Iタイプのうち，3 体は主鉄筋の破断に至る 以前に, せん断スパン内で斜めひびわれが上下に貫通し てせん断破壞した。また，2体は設定した応力振幅での 200 万回の絽返し載荷によっても破壊しなかったので, 試験途中で応力振幅を増加させてある。

せん断破壞したもの以外は, すべて主鉄筋の疲労破断 により破壞に至った。主鉄筋が疲労破断したデータを 図一2 にプロットした。図一2 は最小応力 $\sigma_{s . \min }$, 最大 応力 $\sigma_{s . \text { max }}$, おび鉄筋母材の引張強度 $f_{s u}$ から, 修正 Goodman の関係が成立すると仮定して完全片振り時に 換算した応力振幅 $\sigma_{r 0}$ を式 (1) により求め, 破壞まで の繰返し載荷回数 $N$ との間を両対数で示したものであ る。

$$
\sigma_{r 0}=\frac{\sigma_{s \cdot \max }-\sigma_{s \cdot \min }}{1-\sigma_{s, \min } / f_{s u}}
$$

図一2 中の $S-N$ 直線は, 著者らが既に提案している

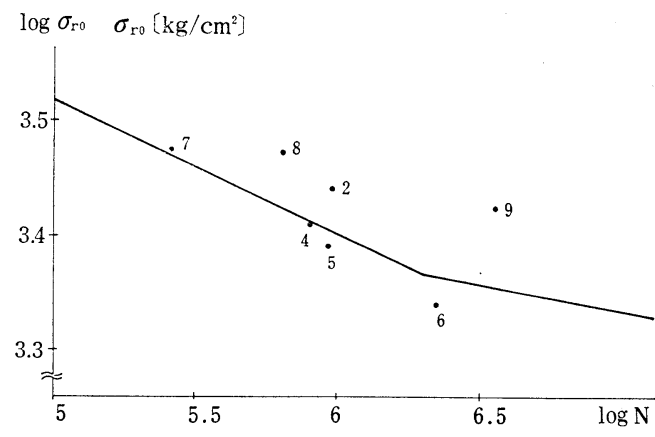

图-2Ｉ タイプの疲労試験結果と $S-N$ 直線1)

異形鉄筋の疲労強度算定式 ${ }^{1)}$ であるこの算定式は疲労 強度の平均值を推定するものである。図一2によれば, 今回の実験より得られた部材全体の疲労破壊までの繰返 し回数 $\log N$ は, 算定式 ${ }^{11}$ にり計算される疲労寿命よ りも幾分大きめの傾向が見られたが，I-9 のデータを除 けばほぼ予測された疲労強度に近いことが認められる。

Iタイプの実験結果は, 悠密には 2 本の主鉄筋のうち のいずれか疲労強度の小さい方の鉄筋の疲労強度に支配 された部材全体としての疲労強度を表していると考えら れるが, 結果的にはほぼ鉄筋単体としての疲労強度と大 きくは異ならなかった。これは, 既に述べたように, 1 本の鉄筋自体が多数のフシを含んでいて，その中の最弱 のフシの疲労強度がほとんど絶対的な最弱フシの疲労強 度に近く, 鉄筋本数が 2 本に増加することによっても全 体としての疲労強度の低下にはほとんど影響を及ぼさな かったためと考えられる。

また，実験に使用した鉄筋の疲労強度が，既に提案し た算定式よりほぼ評価できるということから，今回使用 した鉄筋が他種の鉄筋に比較して特に強い，あるいは弱 いということはなく, 鉄筋母材自体は平均的な疲労強度 を有するものであるとみなすことができる。

\subsection{II タイプの実験結果}

IIIタプとして，20 体のはりを試験した。母材に比 較した場合の疲労強度の低下を見込んで $\sigma_{r}$ は 11.0 $22.3 \mathrm{~kg} / \mathrm{mm}^{2}$ とあらかじめ小さく設定した。また， $r$ は $0.20 \sim 0.40$ の範囲である。これらをランダムに設定し て実験を行った。実験結果は表一2 に示すとおりであ る。IIタイプのはりは，すべて溶接鉄筋の破断により破 壊に至った。IIタイプのうち 3 体は設定した応力振幅で の 200 万回の繰返しによっても破壊しなかったので, 試 験途中で応力振幅を増加させ, 破壊するまで試験を継続 した。

IIIイプは主鉄筋として溶接鉄筋と鉄筋母材を各 1 本 ずつ含むものであるが, 溶接鉄筋の疲労強度が母材に比 較して低いため, まず溶接鉄筋が疲労破断し，そのため 残った鉄筋母材に作用する応力振幅が 2 倍となることに 


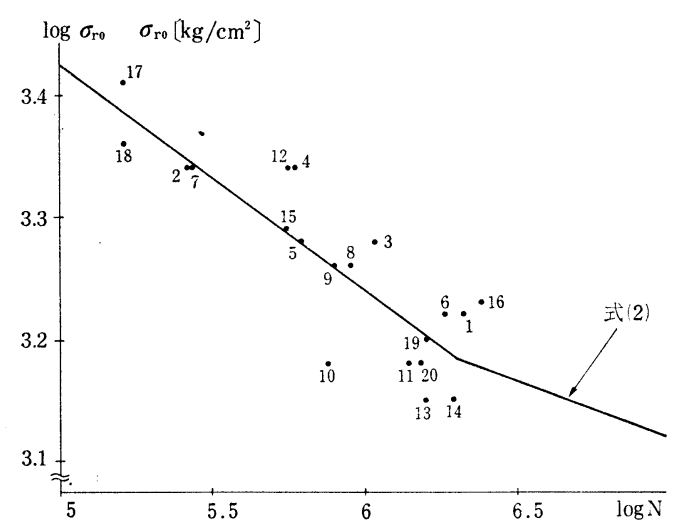

図一3 II タイプの疲労試験結果と $S-N$ 直線（式 (2)）

より，溶接鉄筋の破断後，直ちにはりが破壊したと考え られる。したがって，IIタイプのはりが破壊するまでの 繰返し回数は，溶接鉄筋の破断までの繰返し回数にほぼ 等しいとして議論を進める。

II タイプの $\log \sigma_{r 0}$ と破壊までの $\log N$ の関係を図一 3 にプロットした。図一3 中の $S-N$ 直線は実験データ に対して，以下のようにして求めたものである。すなお ち，Nが 200 万回を超える場合はデータが少なく，回 帰直線を定めることが困難であったが，繰返し回数が 200 万回程度までの場合とそれを上回る場合とでは, デ 一タの傾向から見て鉄筋母材の場合と同様に ${ }^{1)}, \log N$ の増加に伴う $\log \sigma_{r 0}$ の低下の程度が緩やかになってい ると考えられたので，便宜的に 200 万回を超えた場合 には，200 万回以下での回帰直線の勾配を $1 / 2$ に低下さ せることとした。このよらにして得られたIIタイプの疲 労強度算定式を式 (2) に示す。

$$
\left.\begin{array}{ll}
\log \sigma_{r 0}=4.35-0.185 \log N & N \leqq 2 \times 10^{6} \\
\log \sigma_{r 0}=3.77-0.093 \log N & N>2 \times 10^{6}
\end{array}\right\}
$$

ただし, $\sigma_{r 0}:\left[\mathrm{kg} / \mathrm{cm}^{2}\right]$

図一3によれば，実験データは $S-N$ 直線のまわりに ほぼ均等に分布していることが認められる。

\subsection{III タイプの実験結果}

III タイプも II タイプと同様に，20 体のはりを試験し た。 $\sigma_{r}$ は $11.3 \sim 20.0 \mathrm{~kg} / \mathrm{mm}^{2}$ であり，Iタイプよりも さらに幾分小さく設定した。また， $r$ は II タイプ同様 0.20 0.40 の範囲とした。これらの設定もランダムに 行った。実験結果は表一2 に示すとおりである。IIIタイ プも，すべて溶接鉄筋の破断により，はりが破壊した。 IIIタイプのうちの 2 体は I タイプ, II タイプと同様の理 由から, 試験途中で応力振幅を増加させ, 破壊するまで 試験を継続した。

IIIタイプは主鉄筋として溶接鉄筋を 3 本含むものであ る。溶接鉄筋の疲労強度が全くばらつかないならば，III
タイプのはりの疲労強度はII タイプのデータより簡単に 推定できるはずであるが，実際にはそうなっていない。

IIIIイプの破壊状沉を推定すれば次のようになると考 えられる。すなわち, 溶接鉄筋の疲労強度がばらつくた めに，溶接鉄筋のうちでもっとも疲労強度の小さいもの がまず最初に破断する。そのため, 残りの 2 本の溶接鉄 筋に作用する応力振幅が 1.5 倍となることにより, 最弱 の溶接鉄筋の破断後, 残る 2 本の溶接鉄筋が次々に破断 し，ほとんど繰返し回数の対数 $\log N$ が増加することな くはり全体が破壊に至るというものである。

つまり，IIIタイプのはりの破壊を支配するのは，3本 の溶接鉄筋のうちの最弱のものであると考えられるの で, 1 本の溶接鉄笳の疲労強度を表しているIIタイプの データから，簡単にはIIIタイプのはりの疲労強度を予測 することはできないことになる。

図一4にIIIタイプの $\log \sigma_{r 0}$ と $\log N$ の関倸をプロッ

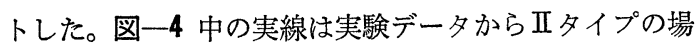
合と同様にして得られる $S-N$ 直線の回帰式である。こ の場合も， $N=200$ 万回を境にして, 勾配を変化させて ある。IIIタイプ疲労強度の回帰式は式 (3) のように表 される。

$$
\left.\begin{array}{ll}
\log \sigma_{r 0}=4.20-0.174 \log N & N \leqq 2 \times 10^{6} \\
\log \sigma_{r 0}=3.65-0.087 \log N & N>2 \times 10^{6}
\end{array}\right\}
$$

\section{ただし, $\sigma_{r 0}:\left[\mathrm{kg} / \mathrm{cm}^{2}\right]$}

図一4 によれば，回帰式を下回る実験データが上回る ものに比較して相対的に少ないこと, および III- 5 , III11 などが他のデータに比較してかなり弱く, 回帰式を 大きく下回っているために, 回帰式全体を下げているこ とが認められる。また，これらのデータを除いては比較 的回帰式に対するばらつきが小さいことも認められる。

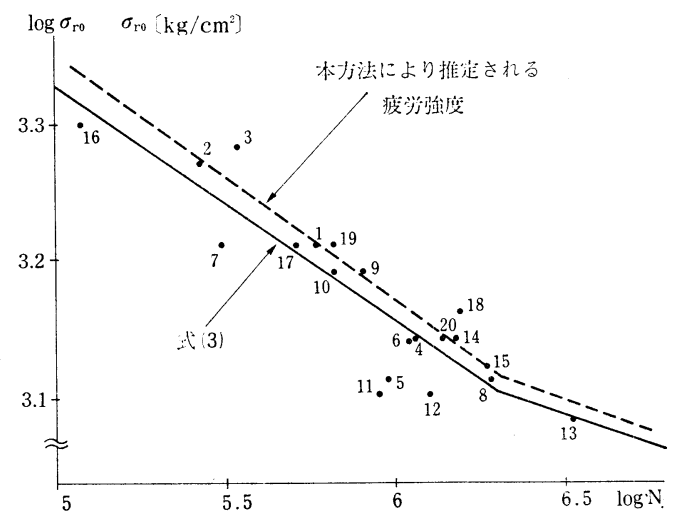

図-4 III タイプの疲労試験結果と $S-N$ 直線（式 (3)) 
4. 溶接鉄筋を 3 本使用した場合の最弱の 溶接鉄筋の疲労強度

\section{1 溶接鉄筋 1 本の疲労強度分布の定量化}

既に述べたように，IIタイプのデータは溶接鉄筋 1 本 の疲労強度を表すと考えられる。このIIタイプの情報を 用いて, IIIタイプのはりの疲労強度を予測できれば, 設 計上非常に有効である。そこで, 3.3 節で述べたように IIIタイプのはりの疲労強度は 3 本の溶接鉄笳のうちの最 弱のものの疲労強度に依存すると考え, 統計的な手法を 用いてIIIタイプのはりの疲労強度を予測することを試み た。

疲労強度の予測に先立って, まずII タイプのデータが どのような分布形をしているかを明らかにしておく必要 がある。IIタイプのデータは同一の応力条件で行ったも のではなく, 設定した各種の応力振幅に対する疲労試験 結果であるので, 実験により得られた疲労強度あるいは 破壊までの繰返し回数をそのまま用いて分布形を調べる ことはできない。

そこで, 実験で与えた $\log \sigma_{r 0}$ と, 破壊までの繰返し 回数 $N$ を用いて式 (2) から算定される疲労強度の計算 值 $\log \sigma_{r 0 . \mathrm{cal}}$ との差 $x$ に着目することとした。

$$
x=\log \sigma_{r 0}-\log \sigma_{r 0 . \mathrm{cal}}
$$

ただし, $\sigma_{r 0}, \sigma_{r 0 . \text { cal }}:\left[\mathrm{kg} / \mathrm{cm}^{2}\right]$

$x$ は対数の差であるので, $10^{x}$ は $\sigma_{r 0}$ と $\sigma_{r 0 . \mathrm{cal}}$ との 比を表す。たとえば, $x$ が負のときは $10^{x}<1$ となり， 実験データが計算値よりも弱いことを意味する。

$x$ の分布形を調べることにより, 実験データの算定式

表一3 II タイプの $x=\log \sigma_{r 0}-\log \sigma_{r 0, \mathrm{cal}}$

\begin{tabular}{c|r||r|r}
\hline 供 試体名 & \multicolumn{1}{|c||}{$x$} & 供 試 体 名 & \multicolumn{1}{|c}{$x$} \\
\hline II- & 0.081 & II-11 & -0.071 \\
II-2 & -0.012 & II-12 & 0.131 \\
II-3 & 0.111 & II-13 & -0.130 \\
II-4 & 0.137 & II-14 & -0.093 \\
II- 5 & 0.005 & II-15 & 0.008 \\
II-6 & 0.058 & II-16 & 0.120 \\
II-7 & -0.009 & II-17 & 0.049 \\
II-8 & 0.026 & II-18 & -0.069 \\
II-9 & 0.003 & II-19 & -0.015 \\
II-10 & -0.180 & II-20 & -0.052 \\
\hline
\end{tabular}

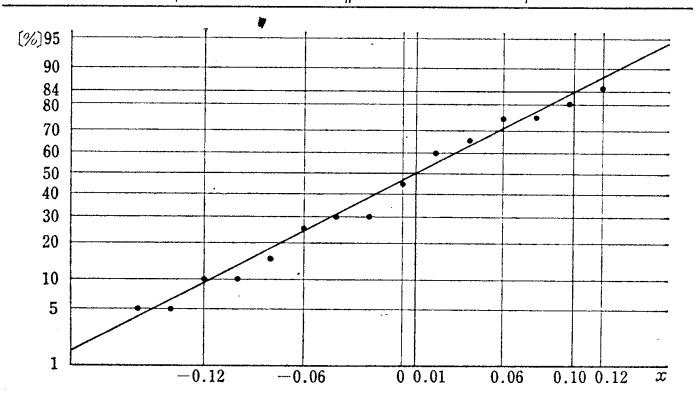

図一5 正規確率紙上での $x$ のプロット
からのばらつきを推定することとした。各データに対す る $x$ の値を表一 3 に示した。 $x$ はこの種の変量の特徴と して正規分布していることが予測されるので， $x$ につい て度数分布表を作成し, その結果を正規確率紙上にプロ ットしてみた (図一5)。

図一5 によれば， $x$ の分布は正規確率紙上でほぼ直線 に近似できることが認められる。したがって, 以後の検 討においては， $x$ は正規分布しているものと仮定するこ ととした。なお, 正規確率紙から読みとれる $x$ の母集団 の平均值は約 0.01 , 標準偏差は約 0.10 である。この值 を一応の参考として, 統計的に母集団の平均, および分 散の推定を行った ${ }^{2)}$ 。

IIタイプの試験結果から得られる 20 個の $x$ をサンプ ル数 20 の標本であると考えれば, 母平均 $\mu$ は標本平均 に, また母分散 $\sigma^{2}$ は標本不偏分散に等しいとして個々 の $x=x_{i}$ から次のように推定することができる。

$$
\mu=\frac{\sum x_{i}}{20}, \quad \sigma^{2}=\frac{\sum\left(x_{i}-\mu\right)^{2}}{20-1}
$$

計算の結果, それぞれ $\mu=0.00, \sigma^{2}=0.088^{2}$ となった。

そこで, 以後の解析においては, $x$ は平均 0.00 , 分 散 $0.088^{2}$ の正規分布に従うとした。したがって， $x$ の 確率密度関数は式 (5) で表される。

$$
\begin{aligned}
f(x) & =\frac{1}{\sqrt{2 \pi} \sigma} \exp \left(-\frac{(x-\mu)^{2}}{2 \sigma^{2}}\right) \\
& =\frac{1}{0.221} \exp \left[-\frac{x^{2}}{0.0155}\right]
\end{aligned}
$$

\subsection{3 本のうちの最弱の溶接鉄筋の疲労強度}

溶接鉄筋を 3 本使用したときは，そのいずれか 1 本の 破断により，他の 2 本に作用する応力振幅が 1.5 倍に なり, 最弱の溶接鉄笳の破断後注としんど $\log N$ が増加 することなくはり全体が破壊すると考えられるので，III タイプのはりは，一つの構成要素の破壊が系全体の破 壊に直接結びっく直列系のシステムに近似できると考え $ろ^{3)}$ 。

したがって, 溶接鉄筋 1 本の平均疲労強度からの偏差 $x$ の 3 本の場合の最小值 $x_{\min }$ の分布形を知ることが できれば, 溶接鉄筋を 3 本使用したはりの疲労強度の平 均值を予測することができる。

溶接鉄筋 1 本に対する $x$ の確率密度関数が式 (5) の上 うに求められたので, 3 本の場合の最小值 $x_{\min }$ の確率 密度関数注式 (6) で求められる。

$$
\begin{gathered}
g\left(x_{\min }\right)=3 f(x)[R(x)]^{2} \\
\text { ただし, } R(x)=1-F(x) \\
F(x)=\int_{-\infty}^{x} f(t) d t
\end{gathered}
$$

式 (6) は, いずれか 1 本の疲労強度の平均疲労強度か らの偏差が $x$ であって，他の 2 本がそれを上回っている 場合を表現している。式 (6) に実際に数值を代大し, 数 


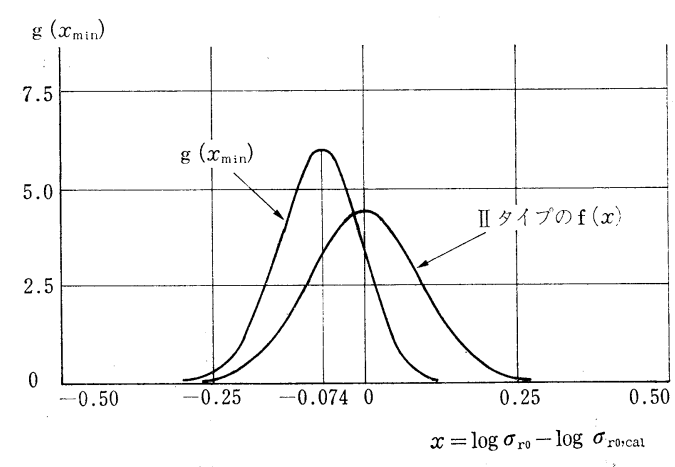

図一6 溶接鉄筋を 3 本用いた場合の $x_{\min }$ の 確率密度関数 $\left[\boldsymbol{g}\left(\boldsymbol{x}_{\mathrm{min}}\right)\right]$

值計算により, $g\left(x_{\min }\right)$ の分布形を求めた。図一6 はこ れをプロットしたものである。図中には $f(x)$ も同時に 示してある。

直感的に予想されるとおり, $g\left(x_{\min }\right)$ の分布形は平均 值が $f(x)$ の平均值よりも小さく, よりばらつきの小さ い集中した形となっている。また, $g\left(x_{\min }\right)$ は厳密には 正規分布ではないが，左右がほぼ対称で，かなり正規分 布に近い形をしていることが認められる。

IIIタイプの場合, $g\left(x_{\min }\right)$ の平均值は -0.074 と計算 されたので，溶接鉄筋を 3 本使用した場合の最弱の溶接 鉄筋の $\sigma_{r 0}$ は, 溶接鉄筋が 1 本の場合の疲労強度算定

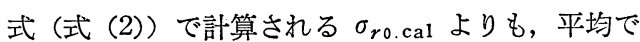
$10^{-0.074} \fallingdotseq 0.843$

すなおち，15.7\% だけ低下していることが予測され る。

5. III タイプのはりの疲労強度の推定值と 実験值との比較

3 本の溶接鉄筋のうち, 最弱のものが破断しても, 残 りの溶接鉄筋に応力が再分配され，なお抵抗することが できれば直ちにはり全体が破壊することはない。そこ で, 最弱の溶接鉄筋から順次破断していくとして, 3 本 の溶接鉄筋のうちの最弱の溶接鉄笳の平均㾉労強度が溶 接鉄筋 1 本の平均疲労強度からどの程度低減しているか を式 (6) により求め, 続いて最弱の溶接鉄筋の破断後 は, 全体の引張力が釣り合うように応力を再分配し, さ らに応力振幅の履歴の影響を Miner 則により考慮する ことにして，3本の溶接鉄筋がすべて破断して IIIタイプ のはりが破壊するまでの繰返し回数を求めた。ただし， 3 本のうちの最弱の溶接鉄筋が破断した以後, 計算上は ほとんど繰返し回数は増加しなかった。

このようにして求めたIIIタイプのはりの疲労強度の推 定值を示したのが, 図一4 中の破線である。計算の結 果, III タイプのはりの疲労強度は II タイプよりも, $\log N=5$ で $15.3 \%, \log N=6$ で $14.9 \%$ の低下となっ た。 4.2 節で述べたように $g\left(x_{\mathrm{min}}\right)$ から計算される最 弱の溶接鉄筋の疲労強度の低下は $15.7 \%$ であったので， 最弱の鉄筋の破断後, 若干繰返し回数が増加しているこ とがわかる。

III タイプのはりの㾉労強度の II タイプからの低減度 がこのように約 $15 \%$ と推定されるのに対して，実験デ ータに基づく低減度は式 (2) と式 (3) の差で計算でき, $\log N=5$ で $19.6 \%, \log N=6$ で $17.6 \%$ となってい る。つまり, 実験データから求まる低減度の方が若干大 きくなっており，この傾向は図一4からも認められる。

ただし， 3.3 節でも述べたように，IIIタイプの実験デ ータのうち，III-11 などがかなり他のデータより弱いた めに回帰式全体を下げていることがわかっている。これ らが何故，他のデータよりも極端に弱いかは不明である が，これらを除いたデータに対しては，図一4 からも明 らかなように，上記の手法を用いて計算した疲労強度は 実験データをほど良く推定できていることが認められ る。

6. 多数本の溶接鉄筋を含む部材の疲労強 度の試算例

実際の施工には多数本の鉄筋を同一箇所で溶接して継 ぐことが多い。この場合の部材全体としての疲労強度を 上記の手法を適用して予測してみる。

溶接鉄筋を $n$ 本同時に使用寸る場合, 溶接鉄筋 1 本の 平均疲労強度加らの偏差 $x$ の最小值 $x_{\min }$ の確率密度関 数は一般的には式 (7) で表される。

$$
g\left(x_{\min }\right)=n f(x) \quad[R(x)]^{n-1}
$$

式 (7) で表される $g\left(x_{\min }\right)$ の平均值を数值的に求め れば, $n$ 本の場合の最弱の溶接鉄筋の疲労強度の平均值 が得られる。そこで, 一つの試算として今回使用した溶 接鉄筋のデータを用い, 本数の増加による最弱の溶接鉄 筋の疲労強度を求め, その破断後は応力を再分配すると して, 順次溶接鉄筋が破断していく状態を調べてみた。 なお, この場合も, 応力振幅の履歷の影響は Miner 則 により考慮した。

図一7 は, このようにして求めた溶接鉄筋の本数の増 加に伴う部材の破壊までの繰返し回数を，初期に与える $\sigma_{r 0}=\sigma_{r 0, i}$ をパラメータとして描いたものである。

図一7 より, 任意の $\sigma_{r 0, i}$ に対して, 疲労寿命は溶接 鉄竻本数が 1 本から 3 本となるにしたがって急激に減少 していくことが認められる。これは, 溶接鉄筋本数が少 ない場合には, 本数のおずかの増加によっても, 疲労強 度のばらつきの影響のために最弱の溶接鉄筋の疲労強度 が小さくなり，これが部材全体の破壊に直接結び付くこ とを示すものである。 


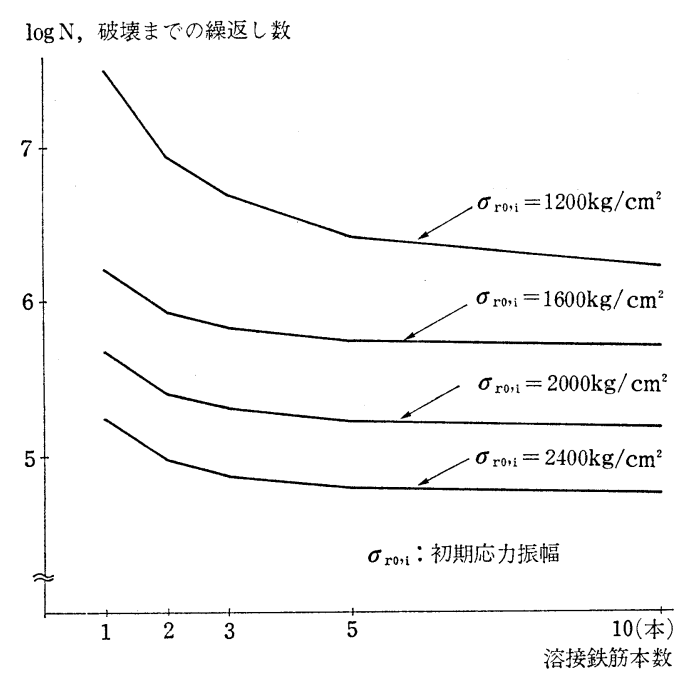

図一7 溶接鉄筋本数の増加に伴う部材の疲労寿命変化

しかし，本数がさらに増加して 10 本程度となった場 合には， $\sigma_{r 0, i}$ がある程度大きければ， 3 本の場合の疲 労寿命とほとんど大差はない。これは, 本数が増加する ことによって, 最弱の溶接鉄筋の疲労強度自体は低下す るものの, その後に起こる応力の再分配によっても応力 振幅が極端に大きくは増加せず，このため最弱の溶接鉄 筋の破断が直接には部材全体の破壊に結び付かないため であると考えられる。

本試算例によれば，今回の実験に使用した溶接鉄筋の 場合，溶接鉄筋本数を 5 本以上とすれば，本数を多くし たことによる疲労寿命の低下をほぼ抑制できることがわ かる。

溶接鉄筋本数が何本以上であれば一般に疲労寿命の低 下を抑制できるかという点については，溶接鉄筋の疲労 特性に依存するものであり，当然使用される溶接鉄筋ご とに異なってくる。しかし，使用した溶接鉄筋の疲労特 性が既知であれば，本論の方法を用いることにより，部 材全体の疲労強度を簡単に予測していくことができると 思われる。

7. 結論

今回行った一連の実験の範囲内で以下の結論を得た。

1）溶接鉄筋を 3 本使用したIIIタイプのはりの疲労試 験によれば，疲労強度が溶接鉄筋 1 本を含むII タイプに 比較して相対的に弱いことが明らかに認められた。それ ぞれのタイプのはりに対する疲労強度の回帰式（式 (2) および式（3））を用いて計算すれば，鉄筋 1 本に作用す る応力振幅 $\sigma_{r 0}$ を $20 \mathrm{~kg} / \mathrm{mm}^{2}$ とした場合に, 疲労寿命 は $\log N=5.7$ から 5.2 へと，また $\sigma_{r 0}=15 \mathrm{~kg} / \mathrm{mm}^{2}$ と した場合には, $\log N=6.4$ から 5.9 へと低下していっ た。
2）実験により得られる溶接鉄筋 1 本の疲労強度の対 数と回帰式により算定される疲労強度の対数との偏差は 正規分布していることが認められた。

3）この偏差に着目し，3本の場合の偏差の最小值の 分布形からその平均值を求め, 3 本の溶接鉄筋のうちの 最弱の溶接鉄筋の疲労強度を予測した。最弱の溶接鉄笳 の破断後, 応力の再分配および応力履歴の変化の影響を 考慮して, すべての溶接鉄筋が破断するまでの繰返し回 数を計算し，これと実験により得られたIIIタイプの疲労 寿命を比較した結果, ほとんどはりの疲労強度をほど良 く推定できることが認められた。

4) 同様の手法を用い, 多数本の溶接鉄筋を同一箇所 に配置した場合についての試算を行った結果，溶接鉄筋 の本数が一定本数以上となった場合には, 本数の増加に よる疲労寿命の低下をほぼ抑制 できることが認められ た。

\section{参 考 文 献}

1) 二羽淳一郎・前田詔一・岡村 甫 : 異形鉄筋の疲労強度 算定式, 土木学会論文集, 第 354 号/ V-2, 1985.2

2) 松本嘉司 : 土木解析法 (I), 技報堂, 1975

3）北川賢司 : 信頼性工学入門, コロナ社, 1981

(原稿受理年月日：昭和 60 年 1 月 16 日) 